\title{
Phytoplankton in three Tatra Mountain lakes of different acidification status
}

\author{
Jan FOTT*, Martin BLAŽO, Evžen STUCHLÍK and Otakar STRUNECKÝ \\ Charles University, Faculty of Science, Department of Hydrobiology, Viničná 7, 128 44, Prague, Czech Republic \\ *e-mail corresponding author: fott@ cesnet.cz
}

\begin{abstract}
Seasonality and depth distribution of phytoplankton were studied in three alpine lakes of the High Tatra mountains: Nižné Terianske Pleso, Dlugi Staw and Starolesnianske Pleso. The lakes differ in size, depth, nutrient status (phosphorus) and acidification status (pH, alkalinity, calcium). The highest biomass was found in the small, shallow, phosphorus - rich and acidified lake Starolesnianske. An extremely low phytoplankton biomass was found in the medium sized Dlugi Staw, which is very poor in phosphorus and which is a transition lake between the acidified and bicarbonate ones. The Lake Nižne Terianske is a standard deep, oligotrophic high mountain lake by most of its characters, phytoplankton included. Most of phytoplankton of the three lakes are flagellates. In the non-acidified Lake Nižné Terianske the taxa contributing most to the biomass are Chrysophyceae (Chromulina and other) and dinoflagellates (Gymnodinium uberrimum, Woloszynskia). In the acidified Lake Starolesnianske the most important groups are green flagellates (Chlamydomonas) and dinoflagellates (Peridinium inconspicuum, Woloszynskia ordinata, Katodinium). The non-motile component (Chroococcus, Oocystis, centric diatoms) is sometimes important in the extremely poor phytoplankton of Dlugi Staw. Moreover, resting stages (mainly stomatocysts) often prevail over active phytoplankton in this lake. Seasonal variation in the amount of chlorophyll per unit biovolume was observed in the lakes Nižné Terianske and Starolesnianske, brought about apparently by changes of the underwater light climate.
\end{abstract}

Key words: phytoplankton, mountain lakes, lake acidification

\section{INTRODUCTION}

Phytoplankton of lakes above the timberline (alpine lakes) of the High Tatra Mountains were studied with the emphasis on taxonomy, floristics (Lukavský 1994) and abundance (Ertl et al. 1965; Juriš \& Kováčik 1987). The paper of Dargocká et al. (1997) seems to be the first study on phytoplankton of high altitude Tatra lakes (Starolesnianske, Ladové) extending single observations to a whole-year study.

Early limnological studies from the High Tatras have revealed that phytoplankton chlorophyll in lakes of pH 4.9-6.3 was always lower than $2 \mathrm{mg} \mathrm{m}^{-3}$, while in more alkaline and more acidic ones it ranged up to about $20 \mathrm{mg} \mathrm{m}^{-3}$ (Vyhnálek et al. 1994). It was shown that the groups of lakes (1) acidic $(\mathrm{pH}<5.0)$, (2) intermediate ( $\mathrm{pH} 5.0-6.2)$ and (3) bicarbonate $(\mathrm{pH}>6.2)$, which are analogous to the groups of Henricksen (1980), can be characterized also by other chemical (alkalinity, calcium) and biological variables (chlorophyll, zooplankton (Stuchlík et al. 1985; Fott et al. 1992; Fott et al.1994).

The project MOLAR (Measuring and Modelling the dynamic Response of Remote Mountain lake Ecosystems to Environmental Change) made it possible to carry out detailed limnological studies of three Tatra lakes above the timber line. The lakes were chosen, among other, according to the criteria of acidity. Starolesnianske Pleso is an acidic lake (group 1), Długi Staw is an intermediate one (group 2) and Nižné Terianske Pleso is a bicarbonate one (group 3). Our objective was to describe phytoplankton of the lakes, showing variation of taxonomic composition and biomass with depth and time, and with acidification status of the lakes.

\section{STUDY SITES AND METHODS}

Characteristics of all MOLAR lakes are summarised by The MOLAR Water Chemistry Group (1999, this issue). The description given here shows how different are the three sites in the Tatras chosen as representatives of bicarbonate, intermediate and acid lakes.

\subsection{Nižné Terianske Pleso}

The lake is located in the Valley Nefcerka $\left(49^{\circ} 10^{`} \mathrm{~N}\right.$, $20^{\circ} 00^{\prime} \mathrm{E}$, Slovakia) at elevation of $1941 \mathrm{~m}$. The lake area is 4.83 ha, catchment area 114 ha, mean depth 18.4 $\mathrm{m}$, maximum depth $44.4 \mathrm{~m}$. Catchment geology: granite, alpine meadows cover about the same area as bare rock. The lake has one main inflow and one outflow. The mean retention time is 290 days (estimate E. Stuchlík). The water transparency is high, Secchi disc readings $12-22 \mathrm{~m}$ (mean $17 \mathrm{~m}$ ). Maximum summer surface temperatures are $8-9{ }^{\circ} \mathrm{C}$. With its mean calcium $150 \mu$ eq $\mathrm{l}^{-1}$, alkalinity $77 \mu \mathrm{eq} \mathrm{l}^{-1}$ and $\mathrm{pH} 6.5$ the lake is classified as a bicarbonate one. Total organic carbon $\left(0.9 \mathrm{mg} \mathrm{l}^{-1}\right)$ and total phosphorus $\left(1 \mu \mathrm{g} \mathrm{l}^{-1}\right)$ are low. Zooplankton: Cyclops abyssorum tatricus, Keratella hiemalis, Polyarthra dolichoptera. There are no fish in the lake. 


\subsection{Dlugi Staw}

The lake is located in the Gasienicowa Valley (49 $13 ' 36^{\prime \prime} \mathrm{N}, 20^{\circ} 00^{\prime} 39^{\prime \prime} \mathrm{E}$, Poland), altitude $1783 \mathrm{~m}$. The lake area is 1.58 ha, catchment area 66 ha, mean depth $5.1 \mathrm{~m}$, maximum depth $10.6 \mathrm{~m}$. Catchment geology: granite, the catchment is covered by dwarf pine, alpine meadow and bare rock. The mean retention time was estimated as about 1 month. The lake's acidification status is intermediate - mean concentration of calcium being $92 \mu \mathrm{eq} \mathrm{l}^{-1}$, alkalinity $0-15 \mu \mathrm{eq} \mathrm{l}^{-1}$ (data E. Stuchlík), $\mathrm{pH}=5.6$. Total organic carbon $\left(0.2 \mathrm{mg} \mathrm{l}^{-1}\right)$ and total phosphorus $\left(<1 \quad \mu \mathrm{g}^{-1}\right)$ are very low. Zooplankton: none in the open water, Chydorus sphaericus and Acanthocyclops vernalis close to the substrate, in very low numbers. The lake is fishless, although brook trout was introduced in 1960.

\subsection{Starolesnianske Pleso}

The lake is located in the Velká Studená Valley (49 $10^{\prime} 48^{\prime \prime} \mathrm{N}, 20^{\circ} 10^{\prime} 4^{\prime \prime} \mathrm{E}$, Slovakia), at elevation of 2000 $\mathrm{m}$. Lake area 0.73 ha, catchment area 2.64 ha, mean depth $1.52 \mathrm{~m}$, maximum depth $4.1 \mathrm{~m}$. Catchment geology: granite. An alpine meadow covers about three quarters of the catchment, the rest is bare rock. The lake has no surface inflow, the surface outflow is visible only at high water levels. Mean retention time 134 days (estimate E. Stuchlík). The Secchi disc readings range from $3 \mathrm{~m}$ to the maximum depth of $4.1 \mathrm{~m}$. Due to its shallowness the lake does not stratify in summer. The highest summer surface temperatures are $10-13{ }^{\circ} \mathrm{C}$. With its low calcium $\left(28 \mu \mathrm{eq} \mathrm{l}^{-1}\right)$, negative alkalinity and low $\mathrm{pH}$ (mean 4.95, range 4.6-5.3) the lake belongs to the most acidified alpine lakes in the Tatras (Stuchlík et al. 1985; Kopáček \& Stuchlík 1994). Summer values of reactive aluminium were $80-130$ in the years under study (1996-98) but values as high as $180 \mu \mathrm{g} \mathrm{l}^{-1}$ were found in 1993. Total organic carbon $\left(4.2 \mathrm{mg} \mathrm{l}^{-1}\right)$ and total phosphorus $\left(8 \mu \mathrm{g} \mathrm{l}^{-1}\right)$ are higher than the average of alpine lakes in the area. Zooplankton: Chydorus sphaericus and Acanthocyclops vernalis both in the shore zone and in the open water. The lake has no fish.

\subsection{Sampling and analytical methods}

Methods of sampling and laboratory analyses are treated by Straškrabová et al. (1999, this issue) except of chlorophyll in phytoplankton, which is described here in full detail.

Determination of chlorophyll- $a$ was carried out fluorometrically. Seston from $50 \mathrm{ml}$ sample volume was separated on Whatman GF/F glass fibre filters by gentle filtration, using a Millipore syringe and filter holder Swinex (diameter $2.5 \mathrm{~cm}$ ). Filters were stored in tightly closed glass tubes filled with $6 \mathrm{ml}$ of $90 \%$ acetone and kept in a freezer. Before analysis $1.2 \mathrm{ml}$ of metanol was added and the mixture was heated to $65{ }^{\circ} \mathrm{C}$ for $2 \mathrm{~min}$ utes (Pechar 1987).
Fluorescence was measured after 20 min centrifugation (4000 RPM) with use of a Turner TD-700 laboratory fluorometer equipped with a non-acidification optical kit. The measurement is based on combination of a blue mercury vapour lamp and specific narrow band interference filters allowing single reading of fluorescence for accurate determination of chlorophyll- $a$ in presence of chlorophyll- $b$ and pheopigments (Welschmeyer 1994). The method was designed for extraction in $90 \%$ acetone but hot extraction in mixture of acetone to methanol 5:1 increases extractibility of most of phytoplankton considerably (Pechar 1987). The fluorometer was calibrated twice a year by an extract of chlorophyll$a$ from freeze-dried cells of a cyanobacterium Synechococcus leopoliensis. Concentration of chlorophyll- $a$ in the extract was determined spectrofotometrically. Further checks were carried out regularly by simultaneous spectrophotometric and fluorometric determinations of chlorophyll- $a$ in lake phytoplankton.

\section{RESULTS}

\subsection{Nižné Terianske Pleso}

The lake was sampled 15 times from August $22^{\text {nd }}$ 1996 to July $18^{\text {th }} 1998$. The depths sampled were 0-15-9-13-17-21-25-29-33-39 or $40 \mathrm{~m}$. The lake was frozen from October $17^{\text {th }} 1996$ to June $15^{\text {th }} 1997$ and from October $23^{\text {rd }} 1997$ to June $15^{\text {th }} 1998$. The range of phytoplankton biomass in all point samples was 0.1-5.9 mg m${ }^{-3}$ chlorophyll- $a$ and $8.5-348 \mathrm{~mm}^{3} \mathrm{~m}^{-3}$ biovolume, respectively (Fig. 1).

Phytoplankton biomass (weighted means according to depth-volume relationship) shows a clear seasonal periodicity (Fig. 2). The seasonal maximum is reached in summer. A secondary peak occurred in late autumn 1998, being terminated by freezing up. The decline of biomass continues under the ice until the minimum value at the end of the ice-cover. The vernal increase continues until the summer peak. Trends of the both variables expressing phytoplankton biomass, chlorophyll- $a$ and biovolume, are almost identical.

Seasonal changes in vertical distribution of phytoplankton biomass are shown by the isopleths of chlorophyll- $a$ and biovolume. Summer deep maxima of chlorophyll were found in all the three study years, although their position on the vertical varied. In 1996 and 1998 they were deeper $(>30 \mathrm{~m})$ than in $1997(20-25 \mathrm{~m})$. The secondary peak of October 1997 had its centre in the 9 m depth (Fig. 3).

The isopleths of biovolume (Fig. 4) have a similar pattern to those of chlorophyll, both of them illustrating deep summer maxima and periods of low biomass in winter. In summer 1997 there was a shallow-water maximum of biovolume not expressed by chlorophyll.

The chlorophyll content of cells $\left(\mu \mathrm{g} \mathrm{mm}^{-3} \mathrm{chl}-a\right)$ is not constant; it is a variable reflecting physiological state of cells. The ratio chlorophyll- $a$ to biovolume (the weighted mean according depth-volume relationship) is 


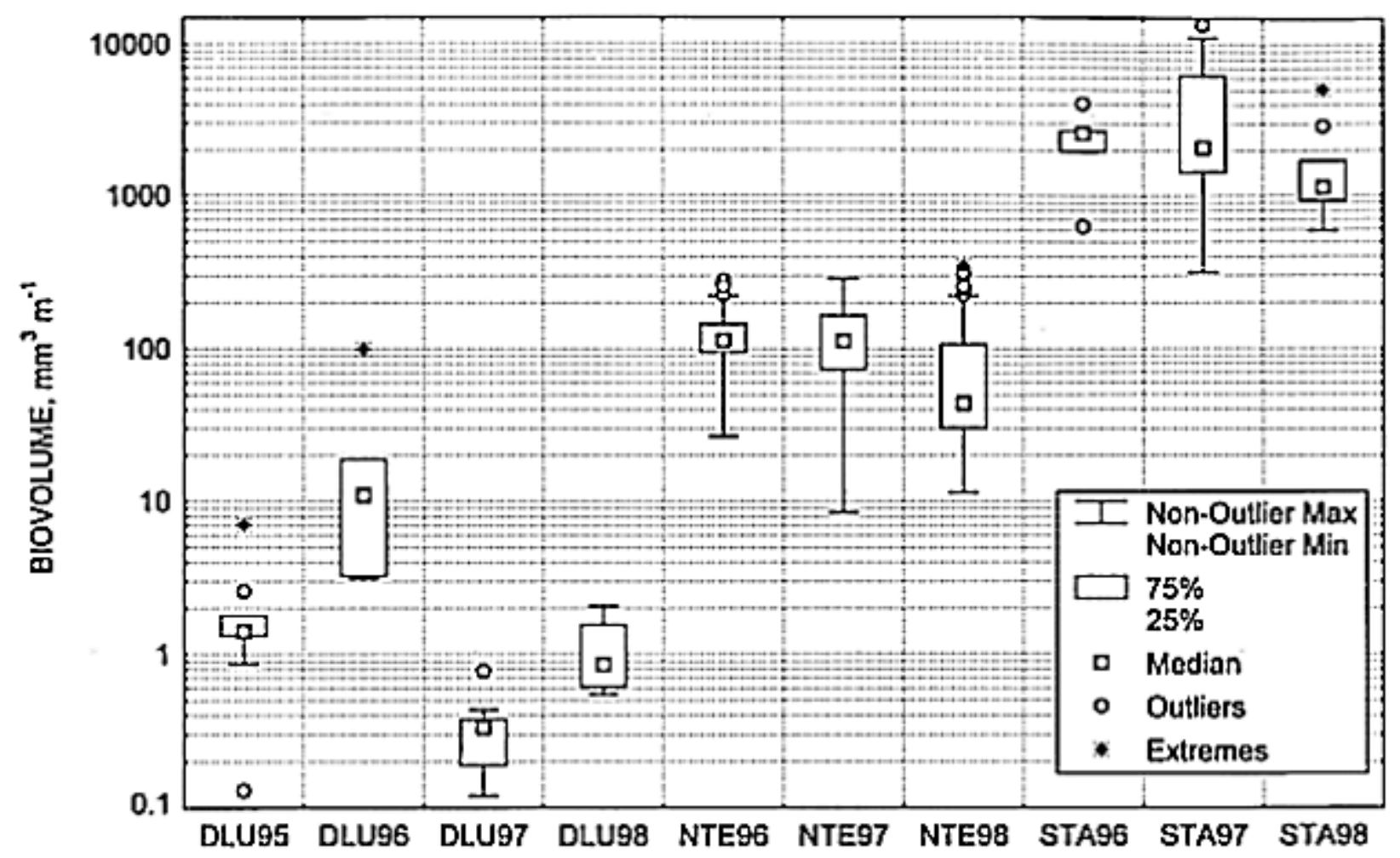

Fig.1. Range, quartiles and medians of phytoplankton biovolume $\left(\mathrm{mm}^{3} \mathrm{~m}^{-3}\right)$ in samples from the lakes Długi Staw (DLU), Nižné Terianske (NTE) and Starolesnianske (STA), 1995 - 1998.

shown on the figure 5a. Maxima are found in summerautumn, minima are at the end of the ice cover. Comparing the ratio from shallow layers (average $1,4,9 \mathrm{~m}$ ) with that one from deep layers (average 25, 29, 33, 40 $\mathrm{m})$ reveals the difference between light and shade adapted phytoplankton (Fig. 5b).

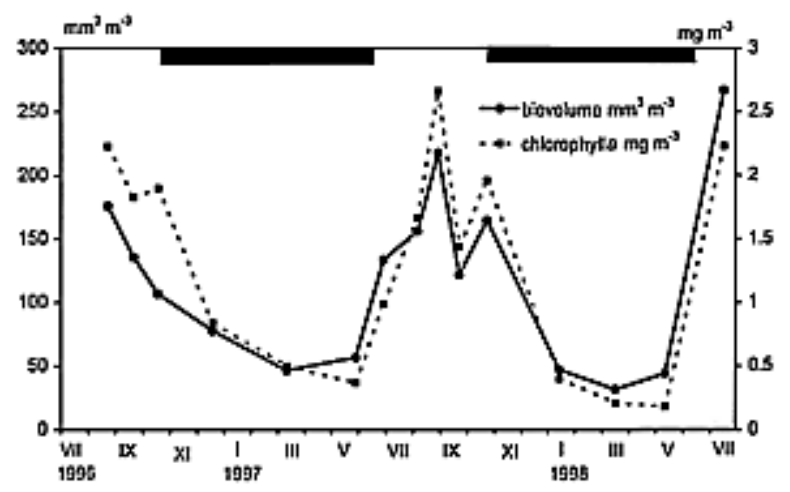

Fig. 2. Seasonal changes of phytoplankton biovolume and chlorophyll- $a$ (weighted means with respect to lake morphometry) in the Lake Nižné Terianske. Ice-cover indicated above.

Our assessment of the qualitative composition of phytoplankton was limited by the possibility of exam- ining preserved samples only. Determination to species was possible only exceptionally; the list of phytoplankters (Tab. 1) gives most taxa on the level of genus and some broad categories of uncertain taxonomic position. The taxa contributing most significantly to phytoplankton biovolume (weighted means with respect to the lake morphometry) are: Woloszynskia and Gymnodinium uberrimum (Dinophyceae), Cryptomonas and Rhodomonas (Cryptophyceae), Chromulina and other unidentified Chrysophyceae (Fig. 6). All of them are flagellates, with the exception of the last group where the proportion of flagellates was difficult to assess. Proportions of the taxa varied with little relation to the season.

The deep summer maximum 1996 was dominated by Cryptomonas; Rhodomonas formed a single deep maximum at the beginning of ice-cover 1997. Woloszynskia contributed significantly to the shallow summer maximum 1997, in the remaining maxima no group of phytoplankton was particularly prevailing.

\subsection{Starolesnianske Pleso}

The lake was sampled 14 times from August $21^{\text {st }}$ 1996 to July $17^{\text {th }} 1998$. The ice cover lasted from November $6^{\text {th }} 1996$ to June $10^{\text {th }} 1997$ and from October $22^{\text {nd }} 1997$ to June $10^{\text {th }} 1998$. Besides the two winter periods there was a short event of ice cover lasting about 
three weeks in September. Because of the shallowness of the lake the single standard sampling depth $1 \mathrm{~m}$ for most variables was chosen. Phytoplankton were sampled from the standard $1 \mathrm{~m}$ depth and also from the surface $(0-0.5 \mathrm{~m})$. The range of phytoplankton biomass was $3.6-19 \mathrm{mg} \mathrm{m}^{-3}$ chlorophyll- $a$ and $585-13,600 \mathrm{~mm}^{3} \mathrm{~m}^{-3}$ biovolume, respectively (Fig. 1). When we include data on chlorophyll that were sampled weekly then the range broadens to $0.4-36 \mathrm{mg} \mathrm{m}^{-3}$ chlorophyll- $a$.

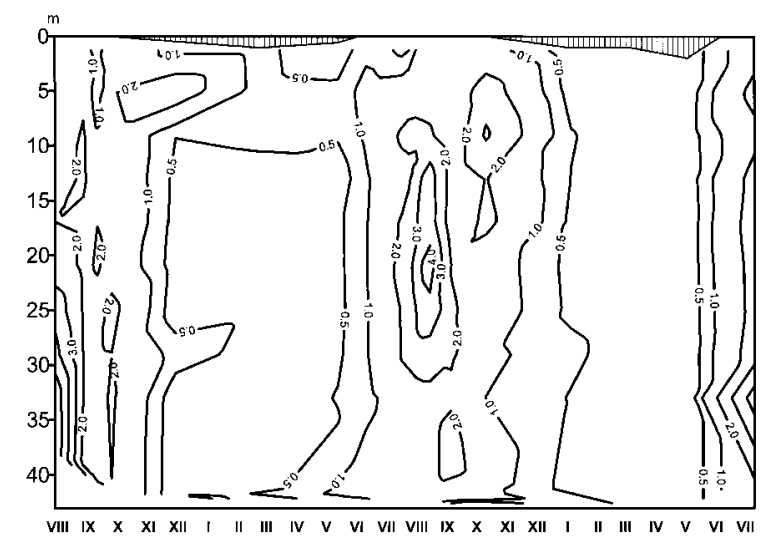

Fig. 3. Nižné Terianske Pleso, isopleths of chlorophyll- $a$ (mg $\mathrm{m}^{-3}$ ).

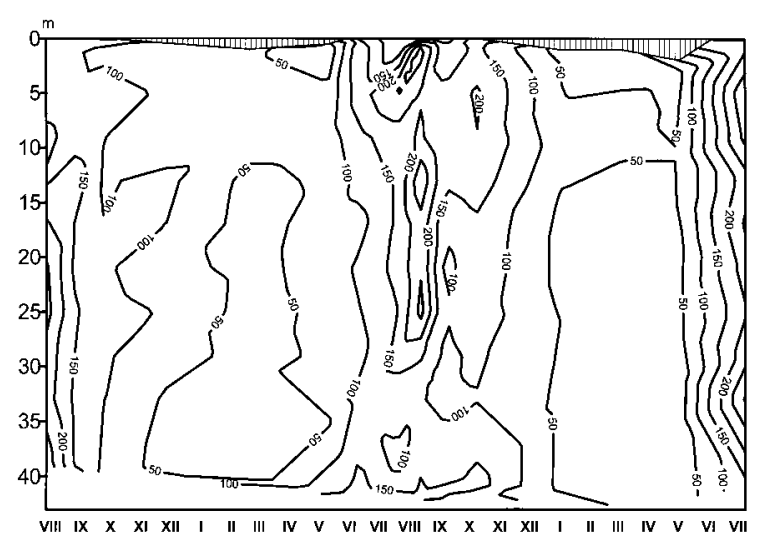

Fig. 4. Nižné Terianske Pleso, isopleths of phytoplankton biovolume $\left(\mathrm{mm}^{3} \mathrm{~m}^{-3}\right)$.

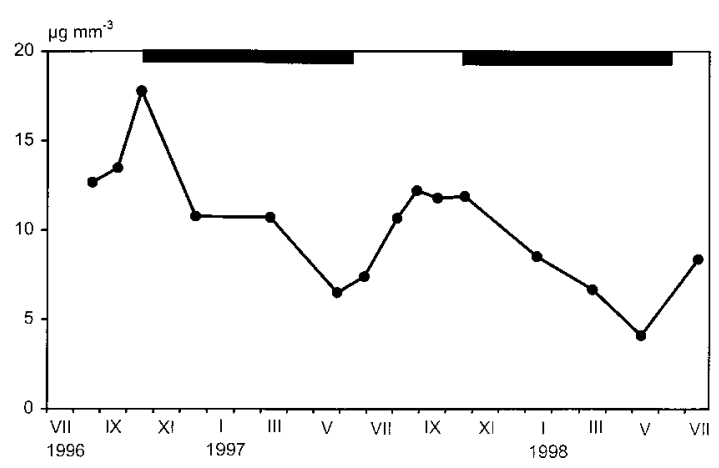

Fig. 5a. Nižné Terianske Pleso, chlorophyll- $a$ per unit biovolume (calculated from weighted means for the whole lake).

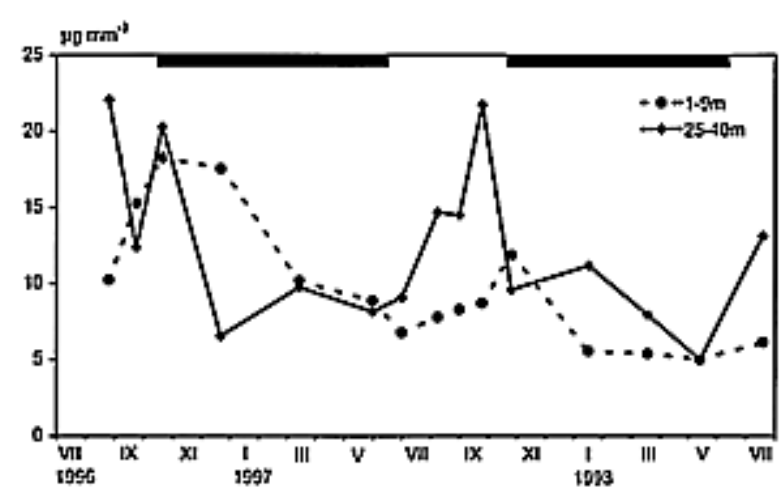

Fig. 5b. Nižné Terianske Pleso, chlorophyll-a per unit biovolume (calculated for the shallow and deep layers separately). Ice-cover indicated above.

Seasonal courses of chlorophyll and biovolume show different patterns, their ups and downs do not coincide (Fig. 7). The peak of chlorophyll from September 1996 is not expressed by a corresponding peak of biovolume, and a similar discrepancy took place in October 1997. Seasonal periodicity of both variables is poor. The chlorophyll content of cells (Fig. 8) varies from 0.5 to $10 \mu \mathrm{g} \mathrm{mm}^{-3}$.

The graphical presentation of qualitative composition (Fig. 9) is based on samples taken from the $1 \mathrm{~m}$ depth. Species most contributing to phytoplankton biomass are dinoflagellates (Peridinium inconspicuum and Woloszynskia ordinata + Kathodinium sp. div.) and green flagellates (Chlamydomonas sp.1, spherical + Chlamydomonas sp.2, ovoid). From the total of 14 samples the four flagellates contributed to the total biovolume by more than $60 \%$ in 12 samples, by more than $90 \%$ in 7 samples. Other important flagellates are Ochromonas crenata and other unidentified Chrysophyceae, mostly flagellates. An important component in terms of cell numbers is a non-motile green alga Koliella cf. longiseta. Because of its small size, however, it does not contribute to phytoplankton biomass significantly. There is no apparent relation of phytoplankton composition to the season.

\subsection{Dtugi Staw}

Długi Staw was sampled 11 times in the ice-free periods of 1995, 96, 97 and 98. The three sampling depths (with minor variations) were 1,4 and $8 \mathrm{~m}$. Phytoplankton biomass was extremely low. The biovolume ranged from 0.1 to $100 \mathrm{~mm}^{3} \mathrm{~m}^{-3}$, but except of summer autumn 1996 most of the samples were under $1 \mathrm{~mm}^{3} \mathrm{~m}^{-3}$ (Figs 1, 10).

Taxa contributing significantly to phytoplankton biovolume are flagellates Woloszynskia (Dinophyceae), Rhodomonas (Cryptophyceae), Chromulina (Chrysophyceae). Other important components are a green alga Oocystis (Chlorophyceae), a centric diatom Cyclotella (Bacillariophyceae) and a cyanobacterium Chroococcus (Fig. 11). The non-motile taxa (Chroococcus, Oocystis) 
Tab. 1: List of phytoplankton taxa found in preserved samples from the lakes Nižné Terianske Pleso, Starolesnianske Pleso and Długi Staw.

\begin{tabular}{|c|c|c|c|c|}
\hline Class & organism & NTE & STA & DLU \\
\hline Cyanophyceae & Chroococcus & $\mathrm{x}$ & $\mathrm{x}$ & $\mathrm{x}$ \\
\hline \multirow[t]{6}{*}{ Dinophyceae } & Peridinium inconspicuum & $\mathrm{x}$ & $\mathrm{xx}$ & \\
\hline & Peridinium & $\mathrm{x}$ & & $\mathrm{x}$ \\
\hline & Gymnodinium uberrimum & $\mathrm{xx}$ & $\mathrm{x}$ & \\
\hline & Gymnodinium & $\mathrm{x}$ & $\mathrm{xx}$ & \\
\hline & Wolozsynskia & $\mathrm{xx}$ & $\mathrm{xx}$ & $\mathrm{x}$ \\
\hline & Kathodinium & $\mathrm{xx}$ & $\mathrm{xx}$ & $\mathrm{x}$ \\
\hline \multirow[t]{2}{*}{ Cryptophyceae } & Cryptomonas & $\mathrm{xx}$ & $\mathrm{x}$ & $\mathrm{x}$ \\
\hline & Rhodomonas & $\mathrm{xx}$ & $\mathrm{x}$ & $\mathrm{x}$ \\
\hline \multirow[t]{11}{*}{ Chrysophyceae } & Bitrichia & & $\mathrm{x}$ & \\
\hline & Dinobryon & $\mathrm{x}$ & & \\
\hline & Ochromonas crenata & & $\mathrm{xxx}$ & \\
\hline & Ochromonas & $\mathrm{x}$ & & \\
\hline & Chrysococcus & $\mathrm{x}$ & & \\
\hline & Chrysolykos & $\mathrm{x}$ & & \\
\hline & Chromulina & $\mathrm{x}$ & $\mathrm{x}$ & $\mathrm{x}$ \\
\hline & Kephyrion & $\mathrm{xx}$ & & \\
\hline & Kephyriopsis & $\mathrm{xx}$ & & \\
\hline & Mallomonas & $\mathrm{xx}$ & & \\
\hline & Chrysophyceae g. sp. div. & $\mathrm{xxx}$ & $\mathrm{xx}$ & $\mathrm{x}$ \\
\hline \multirow[t]{6}{*}{ Bacillariophyceae } & Synedra & $\mathrm{x}$ & & \\
\hline & Navicula & $\mathrm{x}$ & $\mathrm{x}$ & $\mathrm{x}$ \\
\hline & Nitzschia & $\mathrm{x}$ & $\mathrm{x}$ & \\
\hline & Cyclotella & $\mathrm{x}$ & & $\mathrm{x}$ \\
\hline & Stephanodiscus & $\mathrm{x}$ & $\mathrm{x}$ & \\
\hline & Tabellaria & $\mathrm{x}$ & $\mathrm{x}$ & \\
\hline Euglenophyceae & Trachelomonas & $\mathrm{x}$ & & $\mathrm{x}$ \\
\hline \multirow[t]{10}{*}{ Chlorophyceae } & Chlamydomonas sp.1 (spherical) & $\mathrm{x}$ & $\mathrm{xx}$ & $\mathrm{x}$ \\
\hline & Chlamydomonas sp. 2 (ovoid) & $\mathrm{x}$ & $\mathrm{xx}$ & \\
\hline & other green flagellates & $\mathrm{xx}$ & $\mathrm{xx}$ & \\
\hline & Crucigeniella & $\mathrm{x}$ & & \\
\hline & Scenedesmus & $\mathrm{x}$ & $\mathrm{x}$ & $\mathrm{x}$ \\
\hline & Tetrastrum & $\mathrm{x}$ & $\mathrm{x}$ & \\
\hline & Oocystis & $\mathrm{x}$ & $\mathrm{x}$ & $\mathrm{xx}$ \\
\hline & Tetraedron & $\mathrm{x}$ & $\mathrm{x}$ & $\mathrm{x}$ \\
\hline & Koliella cf.longiseta & $\mathrm{x}$ & $\mathrm{xxx}$ & \\
\hline & Elakatothrix & $\mathrm{x}$ & $\mathrm{x}$ & \\
\hline \multirow[t]{3}{*}{ Zygnematophyceae } & Desmidium & $\mathrm{x}$ & & \\
\hline & Cosmarium & $\mathrm{x}$ & & \\
\hline & Staurastrum & $\mathrm{x}$ & & $\mathrm{x}$ \\
\hline
\end{tabular}

were the main component of phytoplankton in the two cases of relatively high biovolume (August and October 1996).

Due to the low biomass of active phytoplankton, resting stages (cysts) are relatively abundant. In 1997 cysts prevailed over active phytoplankton by an order of magnitude (Fig. 12).

\section{DISCUSSION}

\subsection{Comparability of the three lakes}

The three alpine, soft-water lakes were chosen as representatives of bicarbonate, transition and acidified lakes, all of them lying on acid-sensitive, granitic geology. It should be emphasised however, that besides hydrochemistry, the lakes differ by other characters as well. The most notable are different morphometry and hydrology, resulting in different patterns of stratification and different light climate. This makes comparisons difficult.
The present study is rather the first step which should be followed by others, showing how far the three lakes are representative for lakes in the High Tatras and in other high mountain regions of Europe.

\subsection{Levels of phytoplankton biomass}

Established limits of the oligotrophic region on the trophic continuum of lakes are, regarding phytoplankton biomass, $0.02-0.1 \mathrm{mg}^{-1}$ carbon or $0.3-3 \mu \mathrm{g} \mathrm{l}^{-1}$ chlorophyll- $a$ (Lampert \& Sommer 1997). Converting carbon to biovolume and changing units, this corresponds to $100-500 \mathrm{~mm}^{3} \mathrm{~m}^{-3}$ biovolume or $0.3-3 \mathrm{mg} \mathrm{m}^{-3}$ chlorophyll- $a$.

According to this classification Nižné Terianske Pleso is oligotrophic, Starolesnianske Pleso is mesotrophic. Długi Staw is an ultraoligotrophic lake, with its summer values of phytoplankton biomass comparable to Latnjajaure in Lappland, the lake with the lowest phytoplankton as known so far (Nauwerck 1980). 


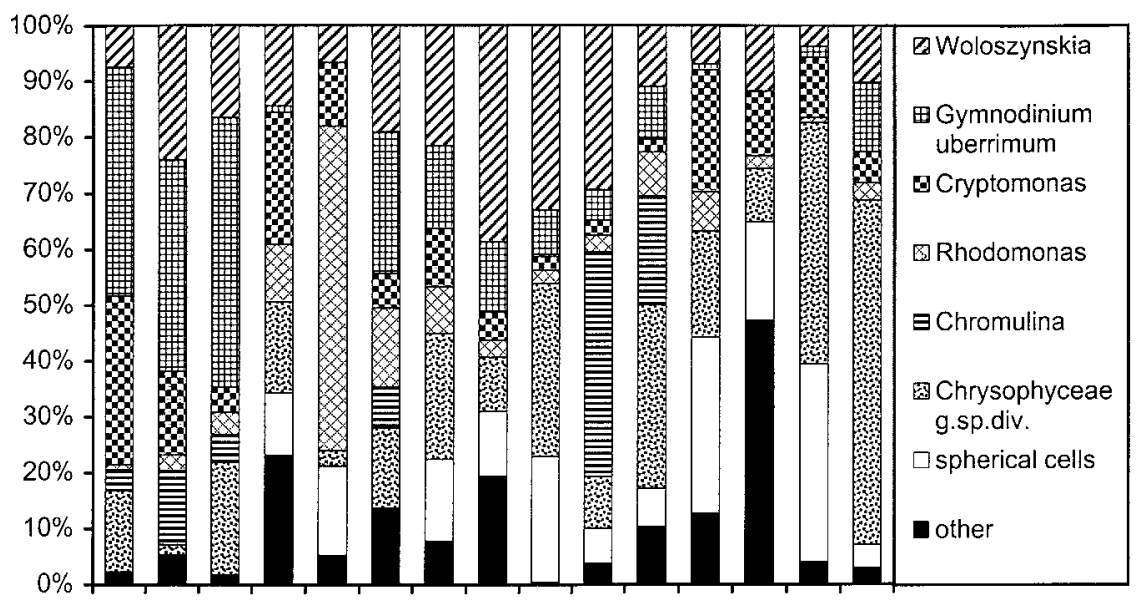

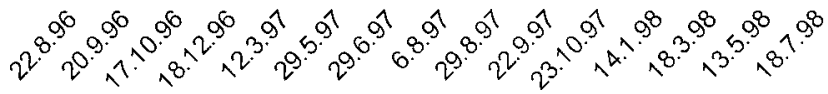

Fig. 6. Nižné Terianske Pleso, percentage biovolume of the main taxa (calculated from weighted means with respect to lake morphometry).

\subsection{Seasonality of biomass}

The widely accepted picture of seasonal periodicity of phytoplankton biomass in a typical deep alpine lake is a simple curve with its maximum in late summerautumn and the minimum shortly before ice-break. The lowest seasonal value falls between $10 \%-20 \%$ of the highest one (Pechlaner 1967). The Lake Nižné Terianske (Fig. 2) is no exception to this rule, and it makes no difference whether biovolume or chlorophyll are chosen as measures of the biomass.

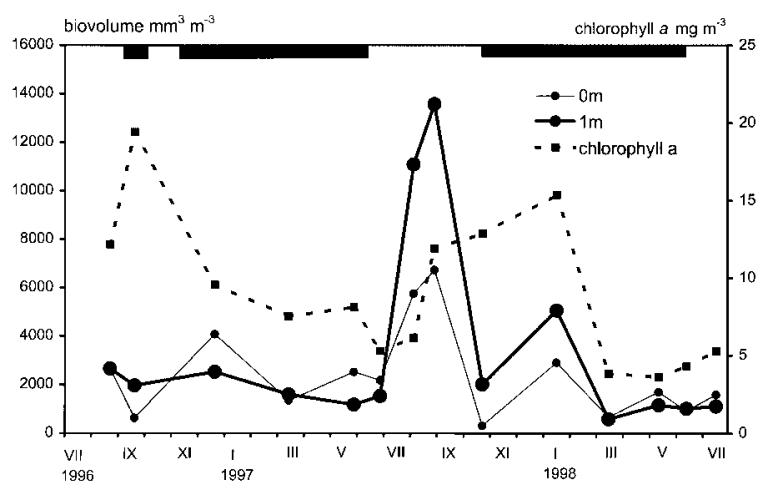

Fig. 7. Starolesnianske Pleso, seasonal changes of phytoplankton biovolume (samples from $0 \mathrm{~m}$ and $1 \mathrm{~m}$ depth) and chlorophyll-a (samples from $1 \mathrm{~m}$ depth). Ice-cover indicated above.

It is worth of mentioning there is a high mountain lake where the seasonality of phytoplankton biomass is completely opposite to that in Nižné Terianske and many other alpine lakes. Lago Paione Superiore (LPS) is a low alkalinity lake in Italian Central Alps (Pugnetti \& Bettinetti 1995; Manca \& Comoli 1999, this issue) where phytoplankton (dinoflagellates, chrysomonads) start to build up the crop in January, peak in March-
April and decline until the thaw. The lowest values are in late summer and autumn. The reasons of the opposite pattern are apparently complex. Lago Paione Superiore is rather shallow (max. depth $11.7 \mathrm{~m}$, mean depth $5.1 \mathrm{~m}$ ) which may bring about less light limitation under ice and more light inhibition after the thaw and in summer. Besides the zooplankter Cyclops abyssorum tatricus which is common in many alpine lakes of the Alps and the Tatras, LPS is inhabited by an efficient filter-feeder Daphnia longispina, capable to build up numbers and biomass that are not common in oligotrophic alpine lakes. In this way the bottom-up control of phytoplankton shifts to the top-down, at least in August-September when the biomass of Daphnia is at the maximum.

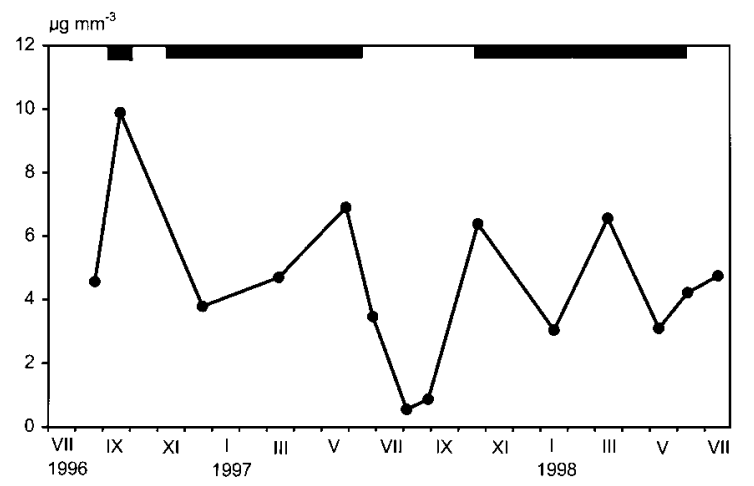

Fig. 8. Starolesnianske Pleso, chlorophyll- $a$ per unit biovolume, $1 \mathrm{~m}$ depth. Ice-cover indicated above.

In the Lake Starolesnianske (Fig. 7) there was a distinct peak of biovolume in summer 1997 but peaks of biovolume and chlorophyll did not coincide. The possible reason might be rapid adaptations, by adjusting the chlorophyll content of cells, to sudden changes of light climate in this very shallow lake. In an earlier study of 


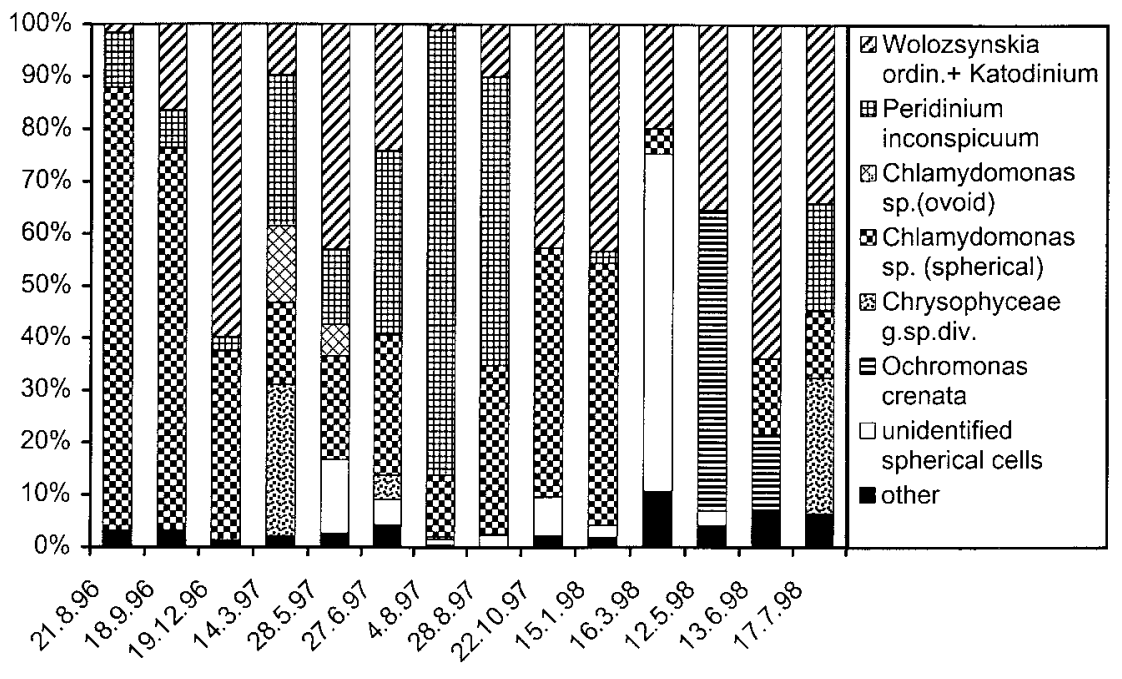

Fig. 9. Starolesnianske Pleso, percentage biovolume of the main taxa, samples from $1 \mathrm{~m}$ depth. this lake covering the years 1990-1991 the values of chlorophyll were found in a similar range (3-24 mg $\mathrm{m}^{-3}$ ), with peaks in both ice-free and ice-covered periods (Dargocká et al. 1997).

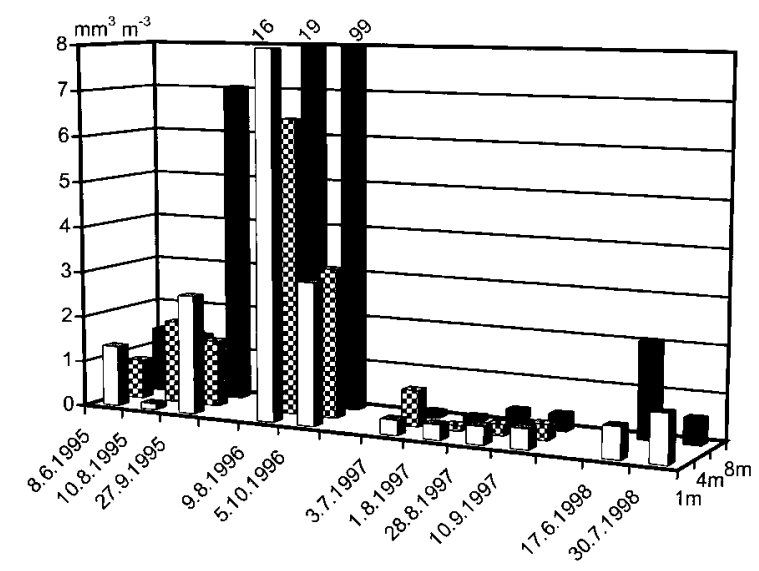

Fig. 10. Dhugi Staw, phytoplankton biovolumes from the depths $0 \mathrm{~m}, 4 \mathrm{~m}$ and $8 \mathrm{~m}$, open-water periods 1995-98.

The third lake (Długi Staw, Fig. 10) was sampled in the ice-free periods only. Comparing the data from the four sampling seasons (Figs 1, 10) we can conclude on a high instability of this ultraoligotrophic lake regarding summer phytoplankton crops. Occasional high flowthrough may be partially responsible. Straškrabová (pers. com.) pointed on fast fluctuations of water level she observed in August 1997, the year of heavy rains and the lowest phytoplankton biomass. But the most likely reason for the extremely low summer phytoplankton is combination of low available phosphorus with light inhibition (the nutrient-dependent light effect, see Pechlaner 1971) in this phosphorus-poor and optically shallow lake. The adverse conditions are reflected by a high proportion of cysts to the active cells.

\subsection{Stratification of biomass}

Typical phenomena in a stratified high-mountain lake are maxima of phytoplankton biomass which occur in deep water in the ice-free period and in shallow water under ice. Shallow summer maxima of light-adapted algae may develop as well (Nauwerck 1966; Pechlaner 1967; Catalan \& Camarero 1990). This pattern was also found in the Lake Nižné Terianske (Figs 3, 4). Our observations show that the position of deep summer maxima on the vertical may vary considerably from year to year. The shallow summer maxima of phytoplankton biomass which are apparent by high biovolume may not be expressed by corresponding maxima of chlorophyll, presumably due to the low chlorophyll content of the light-adapted cells.

\subsection{Light and shade phytoplankton}

In freshwater phytoplankton the amount of chlorophyll per unit biovolume (the specific chlorophyll content) may vary by one order of magnitude. It differs among major taxonomic groups and within a single species it may vary as a result of physiological adaptation. The highest content has been found in chlorophytes (17$\left.20 \mu \mathrm{g} \mathrm{mm}^{-3}\right)$ while in diatoms $\left(1.5-9.3 \mu \mathrm{g} \mathrm{mm}^{-3}\right)$ and in cyanobacteria it is relatively low. Cells grown under low irradiance have higher relative pigment content and, hence, improved capacity to absorb light. The ability to adapt the chlorophyll content, however, was found to be lacking in some species of diatoms (Steemann Nielsen \& Jorgensen 1968; Jorgensen 1969; Reynolds 1984).

Values of the specific chlorophyll content found in the lakes Nižné Terianske and Starolesnianske fall within the limits $\left(1.5-20 \mu \mathrm{g} \mathrm{mm}^{-3}\right)$ chlorophyll- $a$, with some outliers exceeding the limits on the both sides (Figs 5, 8). These belong to the most shade-adapted phytoplankton from hypolimnion of the Lake Terianske 


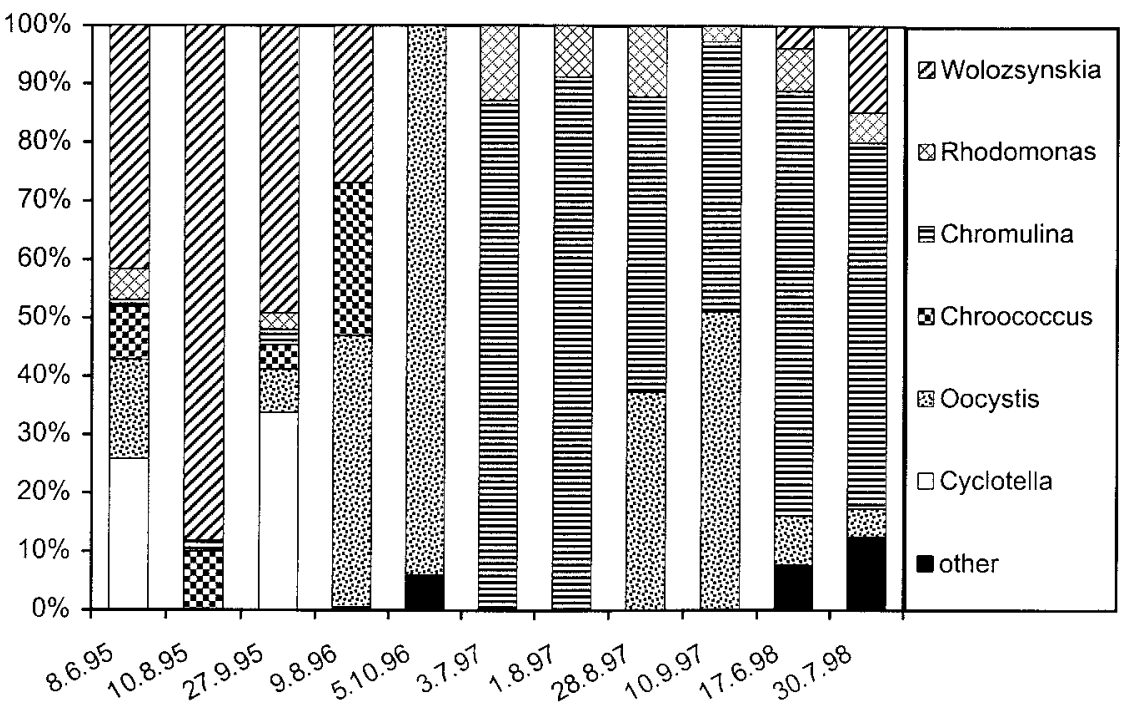

Fig. 11. Dhugi Staw, percentage biovolume of the main taxa, 1996-98
(>20 $\mu \mathrm{g} \mathrm{mm}^{-3}$ ) and the most light-adapted summer phytoplankton from the shallow Starolesnianske Lake $\left(<1 \mu \mathrm{g} \mathrm{mm}^{-3}\right)$.

The specific content of chlorophyll in phytoplankton of a stratified lake can be calculated in two ways. The first one expresses the whole-lake average, taking into account morphometry of the lake. Formally it means expressing total chlorophyll and total biovolume per lake before calculating their ratio (horizontal variation being neglected when data are not available). The figure 5a shows seasonality of such a parameter in the Lake Nižné Terianske. As a whole, phytoplankton in this stratified high-mountain lake have the highest chlorophyll content in late summer-autumn. From the freezeup until the ice-break the chlorophyll content falls down. In a way, the curve of specific chlorophyll content copies the curve of total phytoplankton biomass (Figs 2, 5a).

Secondly, the specific chlorophyll content may be expressed for each sampling depth separately. This was done by Tilzer \& Schwarz (1976, Fig. 5) for phytoplankton of Vordere Finstertaler See, Austria. They found high chlorophyll content in the whole column under the ice in February. In August-October the high values were confined to deep layers only. This was interpreted as adaptation to low light under the ice in winter and in hypolimnion in late summer. The figure $5 \mathrm{~b}$ compares chlorophyll content in phytoplankton of the upper layer (1-9 m) with that of the lower layer (25$40 \mathrm{~m}$ ) in the Lake Nižné Terianske. The deep, shadeadapted phytoplankon can be well distinguished from the light-adapted subsurface phytoplankton, especially in the open-water period.

In the Lake Starolesnianske samples for both chlorophyll and biovolume were taken from $1 \mathrm{~m}$ depth only, the calculated chlorophyll content is supposed to represent the whole lake (Fig. 8). As it could be expected, phytoplankton of this very shallow lake is light-adapted, especially in summer. Despite of occasional high abundance of chlorophytes (Chlamydomonas) the specific chlorophyll content never exceeded $10 \mu \mathrm{g} \mathrm{mm}^{-3}$, which was a typical level of light-adapted phytoplankton at Nižné Terianske. The very low values (under $1 \mu \mathrm{g}$ $\mathrm{mm}^{-3}$ ) in August 1997 were found when phytoplankton were dominated by the dinoflagellate Peridinium inconspicuum (and other dinoflagellates Woloszynsia ordinata and Kathodinium sp.). According to Popovský $\&$ Pfiester (1990) this species (in their book under the name Peridinium umbonatum) may sometimes lack chloroplasts, but this feature could not have been checked with preserved cells.

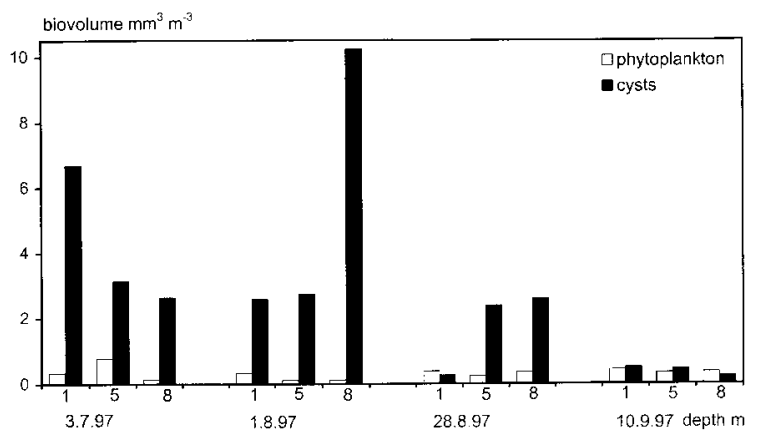

Fig. 12. Długi Staw 1997, biovolumes of active phytoplankton and phytoplankton cysts.

The increase in cell chlorophyll resulting from a temporary deterioration of the light climate may proceed very fast, as it happened after the short-time freeze-up in September 1996. The increase in chlorophyll content was not accompanied by a shift in composition (Fig. 9), which indicates the physiological nature of adaptation in this specific case. 


\subsection{Seasonality of composition, inter-annual variation}

Although the dominance of the major taxa changes throughout the year (Figs 6, 9, 10) we did not find any pattern of seasonal periodicity( Reynolds 1984; Sommer et al. 1986) of phytoplankton composition in any of the three lakes under study. Of course, such a conclusion is warranted only if we have observations covering several years; our data from the lakes Nižné Terianske and Starolesnioanske cover the whole year 1997 and the adjacent half-years 1996 and 1998. Nauwerk (1980) demonstrated the absence of seasonal periodicity in dominance of species by comparing 5 consecutive years at the arctic Lake Latnjajaure; other evidence comes from another lake in Swedish Lappland, the cold monomictic Kuoblatjakkojaure (Nauwerck 1966). He concluded that the irregular character of changes in dominance are brought about by inter-annual variation in climatic conditions. It means, that phytoplankton of these lakes are controlled mostly by allogenic pertubations that vary in their timing from year to year - not by interaction within the community. Our findings show that high mountain lakes of the Tatras may behave in the same manner, regardless they are deep (Nižné Terianske) or shallow (Starolesnianske). The same author (Nauwerck 1966) believes that a regular seasonal periodicity, comparable to that from lowland lakes, takes place in the alpine Gossenköllesee (Tirol, Austria). Comparison of his data (1962) with those gained recently (1996-97) form the same lake during the MOLAR project will be promising.

\section{ACKNOWLEDGMENT}

We are grateful to the European Commission for funding the MOLAR project (contract: ERBIC20 CT96 0021). Our particpation to the project was also supported by the Ministry of Education of the Czech republic (contract: OK 119) to whom we express our gratitude.We would like to thank Jiří Popovský who kindly helped us with determination of preserved phytoplankton. Thanks also to Joanna Galas for carrying out field work and providing us with samples from Długi Staw 1996-98. Thanks are also due to Martin Černý and other members and students of the Department of Hydrobiology, Prague, for help with the field work throughout the project.

\section{REFERENCES}

Catalan, J. \& L. Camarero. 1990. Ergoclines and biological processes in high mountain lakes: Similarities between summer stratification and the ice-forming periods in Lake Redó (Pyrenees). Verh. int. Ver. Limnol., 24: 1011-1015.

Dargocká, J., P. Kneslová \& E. Stuchlík. 1997. Phytoplankton of several high mountain lakes in different stage of acidification. In: Studies on Tatra National Park, 2: 41-62 (in Slovak, with English summary).

Fott, J., E. Stuchlík, Z. Stuchlíková, V. Straškrabová, J. Kopáček \& K. Šimek.1992. Acidification of lakes in the Tatra Mountains (Czechoslovakia) and its ecological consequences. In: Mosello, R., B.M. Wathne \& G. Giussani
(Eds), Limnology on groups of remote lakes: ongoing and planned activities. Documenta Ist. ital. Idrobiol., 32: 6981.

Fott, J., M. Pražáková, E. Stuchlík \& Z. Stuchlíková. 1994. Acidification of lakes in Šmava (Bohemia) and in the High Tatra Mountains (Slovakia). Hydrobiologia, 274: 3747.

Ertl, M., Š. Juriš \& M. Vranovský. 1965. Some remarks about the plankton of the mountain lakes Great and Little Hincovo Pleso in High Tatras. Treatises concerning the Tatra National Park ,8: 57-69 (in Slovak, with English summary).

Henricksen, A. 1980. Acidification of freshwaters - a largescale titration. Proc. int. conf. ecol. impact acid precip., Norway, SNSF project: 68-74.

Jørgensen, E.G. 1969. The adaptation of plankton algae IV. Light adaptation in different algal species. Physiologia Plantarum, 22: 1307-1315.

Juriš, Š. \& L. Kováčik. 1987. Beitrag zur Kenntnis des Phytoplanktons der Hohen Tatra Seen (Tschechoslowakei). Zbor. Slov. nár. Múz., Prír. vedy, 33: 23-40 (in Slovak, with German summary).

Kopáček, J. \& E. Stuchlík. 1994: Chemical characteristic of lakes in the High Tatra Mountains, Slovakia. Hydrobiologia, 274: 49-56.

Lampert, W. \& U. Sommer. 1997. Limnoecology. The ecology of lakes and streams. Translated by J.F. Haney. Oxford University Press, Oxford and New York: 382 pp.

Lukavský, J. 1994. Algal flora of lakes in the High Tatra Mountains (Slovakia). Hydrobiologia, 274: 65-74.

Manca, M. \& P. Comoli. 1999. Studies on zooplankton of Lago Paione Superiore. In: Straškrabová, V., C. Callieri \& $\mathrm{J}$ Fott (Eds), Pelagic food web in mountain lakes. MOuntain LAkes Research Program. J. Limnol., 58(2): 131-135.

Nauwerck, A. 1966. Beobachtungen über das Phytoplankton klarer Hochgebirgseen. Schweiz. Z. Hydrol., 28: 4-28.

Nauwerck, A. 1980: Die pelagische Primärproduktion im Latnjajaure, Schwedisch Lappland. Arch. Hydrobiol./ Suppl., 57: 291-323.

Pechar, L. 1987. Use of an acetone:methanol mixture for the extraction and spectrophotometric determination of chlorophyll- $a$ in phytoplankton. Arch. Hydrobiol. Suppl., 78: 99-117.

Pechlaner, R. 1967. Die Finstertaler Seen (Kühtai, Österreich) II. Das Phytoplankton. Arch. Hydrobiol., 63: 145-193.

Pechlaner, R. 1971. Factors that control the production rate and biomass of phytoplankton in high-mountain lakes. Mitt. Internat. Verein. Limnol., 19: 125-145.

Popovský, J. \& L.A. Pfiester. 1990. Dinophyceae (Dinoflagellida). Süsswasserflora von Mitteleuropa 6. Gustav Fischer Verlag, Jena and Stuttgart: $272 \mathrm{pp}$.

Pugnetti, A. \& R. Bettinetti. 1995. The phytoplankton communities of two acid sensitive lakes (lakes Paione, Central Alps, Italy). Mem. Ist. ital. Idrobiol., 53: 39-52.

Reynolds, C.S. 1984. Ecology of Freshwater Phytoplankton. Cambridge University Press: 384 pp.

Sommer, U., Z.M. Gliwicz, W. Lampert \& A. Duncan. 1986. The PEG-model of seasonal succession of planktonic events in fresh waters. Arch. Hydrobiol., 106: 433-471.

Steemann Nielsen, E. \& E.G. Jørgensen, 1968. The adaptation of plankton algae III. With special consideration to importance in nature. Physiologia Plantarum, 21: 647-654.

Straškrabová, V., C. Callieri, P. Carrillo, L. Cruz-Pizarro, J. Fott, P. Hartman, M. Macek, J.M. Medina-Sánchez, J. Nedoma \& K. Šimek. 1999. Investigations on pelagic food webs in mountain lakes - aims and methods. In: Straškrabová, V., C. Callieri \& J Fott (Eds), Pelagic food web in mountain lakes. MOuntain LAkes Research Program. J. Limnol., 58(2): 77-87. 
Stuchlík, E., Z. Stuchlíková, J. Fott, L. Růžička \& J. Vrba. 1985. Effect of acid precipitation on waters of the TANAP territory. Treatises concerning the Tatra National Park, 26: 173-211 (in Czech, with English summary).

Tilzer, M. \& K. Schwarz 1976. Seasonal and vertical patterns of phytoplankton light adaptation in high mountain lake. Arch. Hydrobiol., 77: 488-504.
Vyhnálek, V., J. Fott \& J. Kopáček. 1994. Chlorophyll-phosphorus relationship in acidified lakes of the High Tatra Mountains (Slovakia). Hydrobiologia, 274: 171-177.

Welschmeyer, N.A. 1994. Fluorimetric analysis of chlorophyll- $a$ in the presence of chlorophyll- $b$ and pheopigments. Limnol. Oceanogr., 39: 1985-1993. 